Drago Jerebic

ORCID: https://orcid.org/0000-0002-6452-3869

University of Ljubljana, Slovenia;

Family Institute Blizina, Slovenia

\title{
Addiction as a Symptom of the Family System
}

\section{The family as a system}

The system theory of the family claims that the family is a living socialemotional organism or system, or a social-emotional organic aggregate of subsystems that are interconnected with the systemic structure of interpersonal interactions, determined by specific rules and roles of a particular family system. ${ }^{1}$ Each family member is part of the entire system and the system is larger than the individual. The family itself is a patient and its currently sick member is only a sign of family dysfunction. ${ }^{2}$ Universal systemic laws were first discovered in the field of biology. German biologist Ludwig Von Bertalanffy defined the system as a number of elements in mutual interaction. He pointed out some of the basic characteristics of the system that form a general system theory. Independently, the psychiatrist Murray Bowen explored the family as an interrelated and integrated social

\footnotetext{
C. Gostečnik, Človek v začaranem krogu, Ljubljana 1997, Brat Frančišek, p. 162.

2 J. Bradshaw, Bradshaw on--the family: a revolutionary way of self-discovery, Pompano Beach, Fla. 1988, Health Communications, p. 27.
} 
system. According to Bowen's theory, the family is a dynamic social organism that works on the basis of mutual influence and interdependence of its members. Causality in such a system is cyclical and non-linear. The family system is a complete system, which means that the whole is greater than the sum of its individual parts. ${ }^{3}$ Each family member is part of the whole and represents the whole. The new perception of the social concept of emotional disorders stems from the systemic understanding of the family, which means that emotional disorders are not solely a trait of one individual but of the whole system. Marriage is the main family subsystem and the emotional stability of the family mostly depends on it. Each member has a specific role. ${ }^{4}$ The essence of the roles is that an individual learns how to be a man or a woman, how to behave, how to express emotions, etc. The role of the child is that he is curious and wants to learn. In an emotionally healthy and stable family, roles are flexible, while unalterable roles are a sign of an unhealthy system. Each family has its own laws and rules that govern the system: they determine the way of everyday life, e.g. how to celebrate, how to care for the body and home, how to manage money, and what the boundaries are. In each system, there is a tension between the need for connectedness and the autonomy of each individual. The family system works on the principle of complementarity. In this way, homeostasis or equilibrium is maintained. ${ }^{5}$ For example, if one member expresses emotions to an excessive extent, another member will express the same emotion to a lesser extent. Family systems can be closed or open. Like individuals, systems have their own needs, such as the need for productivity, maintaining emotional connection, initiative, individuality, diversity as well as connectedness.

\section{The dysfunctional family}

In a functional family, roles are flexible: a member can change a role if it does not fit him, and the system will adjust to it and will not force him to

\footnotetext{
J. Bradshaw, Bradshaw on--the family: a revolutionary way of self-discovery, Pompano Beach, Fla. 1988, Health Communications, p. 28.

4 J. Bradshaw, Bradshaw on--the family: a revolutionary way of self-discovery, Pompano Beach, Fla. 1988, Health Communications, p. 29.

5 J. Bradshaw, Bradshaw on--the family: a revolutionary way of self-discovery, Pompano Beach, Fla. 1988, Health Communications, p. 30.
} 
persist in that particular role. Also, in a functional family, there are very clear boundaries regarding the responsibilities of its members, and children do not have to worry about meeting the needs of the marital or parental subsystem, ${ }^{6}$ which carries the main responsibility within the family system. Thus, children do not carry parental unresolved burdens, and they do not have to worry about parents' satisfaction or the breakdown of the system. In such a family, the child can differentiate at a particular stage of development and later physically leave the family without fear of how the parents will manage on their own. Contrary to this, in a dysfunctional family it is usually the case that even if the child physically leaves the family, she must maintain an emotional connection with it, which she is often not even aware of, and therefore continues to carry certain parental symptoms, which parents no longer have to deal with in/between themselves but in the child. In such a family, children are not allowed to develop their own originality: they must adapt to the needs of the system. This is emotional abuse. ${ }^{7}$ Most often, the child is overly controlled, his emotions are suppressed, the expression of his feelings, needs, thoughts and will that could upset the systemic balance is shamed. As a result, individuals from these families later have difficulty in regulating and expressing their own feelings, needs, thoughts and will because unwanted and often unconscious psycho-biological states are repeatedly awakened within them. According to some authors, ${ }^{8}$ this prevention of the child's actual psychological independence and differentiation is the process of mystification or distorted perception, distorted thinking, and distorted experience.

A functional family is formed by parents who are aware of their own limitations and mistakes. This awareness of their own imperfection arises from regulated affect of shame, which is a fundamental component of

6 C. Gostečnik, Inovativna relacijska družinska terapija, Ljubljana 2011, Brat Frančišek, p. 111; J. Stala, Geistig behinderte Kinder religiös erziehen - Herausforderungen an Pädagogik und Katechese, „The Person and the Challenges” 4 (2014) nr 2, pp. 221-234; J. Stala, Der gesellschaftlich-kulturelle Kontext der aktuellen Gefährdungen für die religiöse Erziehung und Bildung in der Familie, „The Person and the Challenges” 3 (2013) nr 1, pp. 251-266; J. Stala, Der Mensch als Person: Die bestimmende Grundlage für Johannes Paul II. in seinem Bild von der Familie, „The Person and the Challenges” 2 (2012) nr 2, pp. 41-59.

$7 \quad$ P. Love, J. Robinson, The emotional incest syndrome: what to do when a parent's love rules your life, New York 1990, Bantam Books, p. 9.

8 S. Wolinsky, M.O. Ryan, Trances people live: healing approaches in quantum psychology, Falls Village, CT 1991, Bramble Company, p. 7. 
our humanity and is necessary for the psychological balance between the individual and the family system. The psychological balance requires the individual to admit that in certain moments he is helpless and needs help; and to be aware that there is someone or something bigger than him. This can be called God, the Higher Power, or a relationship, i.e. openness to another. ${ }^{9}$ This is not so much about theological reasoning, but rather about the importance of human openness to another, about one's attitude, vulnerability and the ability to accept help from another. In a dysfunctional family, this is not the case with all members, since there are usually "perfect" parents and "imperfect" children who bear the full burden of parental suppressed unprocessed conflicts. In these parents as well as children, the affect of shame is dysregulated. Some authors call it toxic shame; it causes a split either towards perfection, when one feels that he is more than human, or towards degradation, when one feels less than human. ${ }^{10}$ Based on the regulation of shame, dysfunctional families can be divided into three groups. ${ }^{11}$

\subsection{The cultic family}

This is a closed type of family that is flooded with the toxic affect of shame and tries to maintain perfection on the outside. Problems are ignored or minimized. They live in an illusion that everything is fine. Through control and negative feedback, they ensure that no one in the family system deviates in a way that compromises systemic equilibrium. This means that everyone behaves according to the expectations of the parents. In this family, the system is more important than the individual, and its members, especially children or women, often feel stifled and smothered. Manipulation and accusation are two common ways for parents to achieve the desired goals. Often, children are trapped in mutual conflicts because of their parents' needs. There is no place for feeling in this family, only for hard work and sacrifice.

\footnotetext{
9 J. Bradshaw, Healing the shame that binds you, Deerfield Beach 1988, Health Communications, p. 160.

10 J. Bradshaw, Healing the shame that binds you, Deerfield Beach 1988, Health Communications, p. 67.

11 J. Bradshaw, Creating love: the next great stage of growth, London 1992: Bantam Books, pp. 35-44.
} 


\subsection{The chaotic or permissive family}

Is often the very opposite of the cultic or closed family. While in the first one there are too many rigid rules, these are almost absent in a chaotic family, or they are very unstable and changing. This type of family is often shaped by parents whose family was too closed and now they unwittingly gravitate towards another extreme. They ignore pain and avoid problems, and unresolved problems are transmitted from generation to generation. Relationships between family members usually lack emotional boundaries and lead to relationship dependence. Parents can be very strict at one point, while in the next moment they behave like wounded individuals or children who need to be taken care of. Therefore, the roles of parents and children are often interchanged resulting in parentified children and emotional abuse. Typical of these families is parental divorce, as well as double messages, which results in children being overwhelmed with uncertainty and confusion.

\subsection{The corrupt family}

The third type of dysfunctional family also has characteristic affect regulation. While the cultic family is characterized by superiority and the chaotic family by inferiority, in the so called corrupt family there is no sense of shame, because no sense of boundaries has been established among its members. Just like in the cultic family, they live in an illusion that they have no problems, even though there is typically a lot of crime, prostitution and illicit drug abuse. This is due to a very intense unprocessed affect of anger that does not find a constructive outlet, so they sink into the criminal subculture and then erupt in the form of violence to the outside world, to innocent people. This is the exact reflection of their situation: what has happened to them is now being transferred to new innocent people who thus become new victims of unprocessed terror. While the boundaries with the outside world are very sharp, they often do not exist inwardly. The result is psychological, physical and sexual abuse of children. The child thus becomes the bearer of parental destructive affects of shame, disgust, unworthiness, and guilt. ${ }^{12}$

12 J. Bradshaw, Family secrets: what you don't know can hurt you, London 1995: Bantam Books, p. 62. 
All three types of dysfunctional families are characterized by mystified or distorted relationships ${ }^{13}$ and distorted expressions of love. In the cultic family this is reflected in the rule that if you want to be accepted and loved, you must submit yourself, regardless of consequences. In the chaotic family, the rule is that you will only be loved if you love me first, and in the corrupt family, the manifestation of love is that we stick together, and everything is subordinate to this, even unethical acts.

\section{Addiction as a disease of the whole family}

Addiction is a disease or disorder of the whole family, not just of an individual. Here we can point out three elements that illustrate and confirm this thesis. Firstly, addiction takes place within a family. The socalled disease model states that for addiction to occur, neuro-chemical vulnerability or hereditary tendency is very important, and the sociological model claims that e.g. alcoholism is largely a result of social learning in the family, a parental example. Both theories are confirmed by the psychological model that understands alcoholism as a result of unconscious defensive mechanisms, in particular identification with a violent figure in the family. Within the tradition of family therapy, Bowen's multigenerational systemic approach $^{14}$ directly addresses the impact of the past on the present, and in that connection, the transmission of addiction through psychological links and through the model of social learning. Therefore, it emphasizes the importance of differentiation in the resolution of the heritage of addiction. Similar emphasis on the impact of the past on the present is provided by various psychodynamic family therapies. ${ }^{15}$

The second characteristic that speaks in favour of the thesis that alcoholism is a family disease is the concept of the so-called identified patient; in the terminology of family therapy, it is only a symptom of family dysfunction, although it is first seen solely as an individual's problem. Thus,

13 S. Wolinsky, M.O. Ryan, Trances people live: healing approaches in quantum psychology, Falls Village, CT 1991, Bramble Company, p. 20.

14 C. Gostečnik, Sistemske teorije in praksa, Ljubljana 2010: Brat Frančišek; C. Gostečnik, Inovativna relacijska družinska terapija, Ljubljana 2011: Brat Frančišek.

15 J.D. Levin, Couple and family therapy of addiction, Northvale, N.J.; London 1998, Jason Aronson, p. 7. 
the addict can be identified as a family scapegoat ${ }^{16}$ who, with his defiant behaviour, strengthens family cohesion, or becomes the target where other family members direct their own anger and unresolved conflicts and affects. In other words, the addict is indispensable for the maintenance of family homeostasis or equilibrium. ${ }^{17}$ Because of his problems, other family members are distracted from their various unconscious intrapsychic and interpersonal contents so that they cannot emerge in their consciousness.

The third feature that supports the thesis that addiction is a disease or a disorder of the whole family is the fact that most rehabilitation centres around the world have either specific therapeutic programs for the relatives of addicts or otherwise include them in the treatment process. This thesis is also confirmed by the movement of adult children of addicts and related literature, as well as the movement of the codependent. Similarly, various family-based approaches include other family members in the therapeutic process. $^{18}$

\section{Roles in the addictive family}

The addictive family has been described and defined from a wide range of perspectives, some of which are quite contradictory. Some authors have used research, others have written more intuitively, and some were based on clinical practice. Virginia Satir and Sharon Wegschieder-Cruse described a series of roles played by children in addictive families. Wolin studied the transgenerational transmission of alcoholism. Peter Steinglass observed the functioning of an alcoholic family in everyday life. John Bradshaw pointed out how a dysfunctional family is driven by addiction, power, and control. ${ }^{19}$

Central, and most frequent roles, in these families are the hero, the parentified child, the lost child, the clown, and the scapegoat. The hero ${ }^{20}$

\footnotetext{
16 C. Gostečnik, Relacijska družinska terapija, Ljubljana 2004, Brat Frančišek, p. 110.

17 C. Gostečnik, Inovativna relacijska družinska terapija, Ljubljana 2011, Brat Frančišek, p. 12.

18 C. Gostečnik, Sistemske teorije in praksa, Ljubljana 2010, Brat Frančišek, 61.

19 J.D. Levin, Couple and family therapy of addiction, Northvale, N.J.; London 1998, Jason Aronson, p. 163.

20 C. Gostečnik, Inovativna relacijska družinska terapija, Ljubljana 2011, Brat Frančišek, p. 122.
} 
learns and understands early on that in some important parental functions, mother or father are incompetent, and he takes on a certain responsibility which was previously lacking. As a result, this child is deprived of his own childhood and is full of unprocessed affect of anger, and it is very difficult for him to let go of compulsive worrying. These children are often very successful and prone to perfectionism. Nevertheless, deep inside they feel that they were deceived as children. The lost child ${ }^{21}$ suffers from parental emotional distancing, and often also from neglect and feels lost, unloved, and does not know what to do in life. His way of adapting to the family situation is that he is able to withdraw, hide, be invisible, and therefore he has problems with integrating into various groups. The clown's role is to cheer others, especially those who are addicted or depressed, as well as himself. He hides his disappointment behind his manic defensive posture. The scapegoat is the child who is the target of emotional or physical violence and carries rage. Usually there is also the rebel, ${ }^{22}$ which is probably the healthiest role if the rebellion stops in time, otherwise it is very likely that this child will be the carrier of addiction in the next generation. The last two roles are often combined into one. Generally, children in addictive families do not have only one role. The description of these roles can be very helpful for individuals to better see the structure and dynamics of their family and to regulate their experience. This reduces their anxiety and they can calm down easier and sooner when they understand that despite unpredictable and chaotic circumstances in the family, all this happens according to some predictable laws.

\subsection{The compulsive family}

Compulsiveness is part of any addiction. It reflects an utter lack of freedom, when an individual is driven to compulsive behaviour, even if it is to his detriment. When an individual ceases to drink alcohol, he stops alcohol addiction, but this does not mean that this is also the end of compulsive behaviour. Often, his compulsion moves to another area, e.g. work or eating. ${ }^{23}$

\footnotetext{
21 C. Gostečnik, Inovativna relacijska družinska terapija, Ljubljana 2011, Brat Frančišek, p. 130.

22 C. Gostečnik, Inovativna relacijska družinska terapija, Ljubljana 2011, Brat Frančišek, p. 124.

23 P. Flores, Addiction as an attachment disorder, Jason Aronson 2004, p. 5.
} 
A compulsive family prototype is the family with alcoholism. These parents have internalized the so-called harmful or toxic shame, which means that they feel something is irreparably wrong with them, and consequently, they create such families where children feel very similarly precisely because of the experience of chronic rejection. These children, thus, become equally compulsive and continue the cycle. The feeling of shame and of being rejected is transferred to children by parenting methods such as: excessive and uncontrolled use of power, control, perfection, criticism, judging and expressing anger. With these methods, which are actually defence mechanisms, parents make sure that they do not have to come into contact with their own feelings of rejection and shame. Such child-rearing which supports the transmission of a disruptive form of shame from parents to children, is authoritarian, also known as toxic pedagogy. In spite of that, children are forced to idealize their parents, because this is the only way to survive in difficult circumstances, which facilitates the internalization of parental contents. ${ }^{24}$ Therefore, as long as the alcoholic or addict does not face his compulsion, he has not yet faced his addiction. The healing of compulsivity means working with sadness, ${ }^{25}$ rejection and shame - painful feelings that the individual felt as a child and suppressed them because he did not have the proper leverage and support to succeed at the time. Compulsion disables an individual's will and distorts or narrows his thinking. Human life is no longer a conscious choice, but a compulsion.

For a better understanding we will present two views on a family with alcoholism issues.

\section{The family with alcoholism issues}

In his book Couple and Family Therapy of Addiction, Levin (1998) presents two views on a family with alcoholism. ${ }^{26}$ The first was designed by Peter

\footnotetext{
24 J. Bradshaw, Healing the shame that binds you, Deerfield Beach 1988, Health Communications; G. Astrei, A. Bevere, Starševske zmote, Celje 2009, Celjska Mohorjeva družba; Društvo Mohorjeva družba, p. 97.

25 J. Bradshaw, Healing the shame that binds you, Deerfield Beach 1988, Health Communications, p. 173.

26 J.D. Levin, Couple and family therapy of addiction, Northvale, N.J.; London 1998, Jason Aronson, pp. 164-170.
} 
Steinglass, ${ }^{27}$ who sees the addictive family as an organism that solves its problems and has adapted to the disease and occasionally uses the disease to solve a problem or a standstill in the life of the family. The author of the second view is John Bradshaw, who sees the addictive family as dysfunctional and thus causing deep wounds to the children. ${ }^{28}$ While Steinglass strives to support his thesis by thorough empirical research, Bradshaw, in addition to research, shapes his view on the basis of experience from clinical practice: he claims that the origin of addiction should be sought in narcissistic wounds and childhood deficits. Steinglass understands the addictive family as a functional family with a problem, while Bradshaw sees it as more chaotic and disorganized due to addiction. Both refer to their research data, which differ from one another. Bradshaw states that over $60 \%$ of adult children of alcoholics were physically abused and that over $50 \%$ of incestuous fathers were alcoholics, while Steinglass claims that families with alcohol problems are fairly stable, much less chaotic and violent ${ }^{29}$ in comparison to Bradshaw's data. Bradshaw is very clear and normative in defining what a healthy and functional family is, and he assesses families according to these criteria. For Steinglass, however, all families are trying, more or less successfully, to overcome life problems they encounter, including addiction. The difference between the two authors is also in the family goal: the Steinglass' family wants to achieve satisfaction, while Bradshaw's wants to achieve resolution, in an emotional as well as spiritual sense. This difference can be partly explained by the Steinglass interpretation ${ }^{30}$ of the biblical passage where an intoxicated father impregnates his daughters and thus ensures the continuation of his family. Steinglass interprets this as a solution to a family problem that would not be possible without alcohol, whereas someone else would first see the abuse and seek the transmission of trauma to the next generations. ${ }^{31}$

\footnotetext{
27 P. Steinglass, The Alcoholic family, New York 1987, Basic Books, pp. 50-53.

28 J. Bradshaw, Healing the shame that binds you, Deerfield Beach 1988, Health Communications, p. 130.

29 J.D. Levin, Couple and family therapy of addiction, Northvale, N.J.; London 1998, Jason Aronson, p. 165.

30 P. Steinglass, The Alcoholic family, New York 1987, Basic Books, p. 6.

31 J.D. Levin, Couple and family therapy of addiction, Northvale, N.J.; London 1998, Jason Aronson, pp. 166.
} 


\subsection{Steinglass and the family with alcoholism}

Steinglass distinguishes between the alcoholic family, which is organized around alcohol, and the family where alcohol is present, but addiction does not dominate its life. ${ }^{32} \mathrm{He}$ is focused on how both families achieve life goals, regardless of whether this way is appropriate or inappropriate. He reports that the first type of family is much more stable, less chaotic, less marked by violence and sexual abuse than reported by clinical and popular literature. This raises the question of how much his perception of the family is marked by his denial and other defensive mechanisms, such as idealization. Namely, due to their work with transference, and thus often unconscious and denied contents, therapists have access to different data than researchers. In his research, Steinglass focused on the effect alcoholism had on the daily life of the family, family rituals and the ways of solving problems. He found that the families who managed to maintain everyday family rituals were not addictive and suffered less devastating consequences of alcoholism. His two colleagues $^{33}$ claim that the preservation and protection of family rituals is the variable that separates "healthy" alcoholic families from "unhealthy" ones. Clinical practice, on the other hand, states that children of alcoholics remember holidays as the most painful moments and periods in their family life cycle. They are right, however, when in their definition of a "healthy" family they claim that those families who have stable family rituals usually do not come to treatment. In their opinion, this is key to the transmission of alcoholism to the next generation, or the creation of a new family. If a child from an alcoholic family can establish rituals where alcohol does not play a significant role or is not present at all, then this transmission will not occur, or will soon end. This will more likely happen if the child comes from a family where these rituals have been largely protected against the negative effects of alcoholism. Steinglass also disagrees with the phrase "dysfunctional family"; in his opinion it is redundant. According to him, we could understand addiction only as an addictive phase of a family struggling to overcome this obstacle.

According to Steinglass, family reorganization is a consequence of abstinence. ${ }^{34}$ This disagrees with Bradshaw and the 12 step movement who

\footnotetext{
32 P. Steinglass, The Alcoholic family, New York 1987, Basic Books, pp. 117-124. S.J. Wolin, L.A. Bennett, Family rituals, "Family process" 23 (1984) 3, p. 401. P. Steinglass, The Alcoholic family, New York 1987, Basic Books, p. 329.
} 
are convinced that alcoholism is a response to a systemic and intrapsychic disorder. Therefore, in addition to establishing physical abstinence, it is, first of all, necessary to remove the disorder, to reorganize the family; only then can long-term, or the so-called psychological abstinence, begin, which means that in the background there is no compulsion which would propel addictive behaviour.

\subsection{Bradshaw and the dysfunctional family}

The work of the therapist John Bradshaw had a remarkable impact on the treatment of addictions. On the basis of system theory he created his fundamental starting point regarding addiction: addiction is a family disease that is maintained and transmitted from generation to generation through the methods of toxic pedagogy, which was extensively covered by Alice Miller. ${ }^{35}$ This means that the children's self or will must be broken, so that the child is more easily controlled and led, which reduces the child to the level of an object. Most often, this happens if the child was emotionally, physically or sexually abused. Consequently, the child is ashamed, feeling that something is irreparably wrong with him, which Bradshaw calls "toxic shame." ${ }^{36}$ His work highlighted the importance of regulating the affect of shame in the process of addiction treatment. His treatment guidelines represent the synthesis of the systemic (family as a system), psychodynamic (work with suppressed memories and dreams) and cognitive-behavioural (cognitive restructuring and self-efficacy training) approach. He places great importance on working with the "inner child."37

His conception of an addictive family, characterized by violence, rage, incest and all sorts of abuses, was strongly influenced by the already mentioned Alice Miller, whose writing was highly marked by Nazism and the Holocaust. These two phenomena undermined the belief that people are always merely good-natured and provided an insight into how a certain form of child-rearing allows individuals to behave in a markedly pathological,

\footnotetext{
35 A. Miller, For your own good: hidden cruelty in child-rearing and the roots of violence, London 1983, Farrar, Straus, Giroux, p. 59.

36 J. Bradshaw, Healing the shame that binds you, Deerfield Beach 1988, Health Communications; p. 22.

37 J. Bradshaw, Homecoming: reclaiming \& championing your inner child, London 1990, Bantam Books, p. 57.
} 
abusive or criminal manner. Bradshaw sees the source of addiction in a family where children are raised in a pathological or abusive way. Addiction helps a person not feel what hurts or upsets him, i.e. the feelings of embarrassment, pain, guilt, rejection, loss, grief and loneliness. Great emphasis is given to the process of individuation; healthy relationships are only possible for those who feel integrated and fulfilled in themselves, and are therefore able to connect with another for love and not for some unfulfilled need. In this context, he emphasizes that it is necessary to let go of imaginary bonds, symbiotic relationships with parents, the benefits and protection of addiction, and to face one's inner child. By emphasizing the importance of surrender, the acceptance of existential loneliness and communication with one's inner child, he actually speaks of the so called "spiritual awakening", thus showing he is very close or coming from the 12 -step movement. ${ }^{38}$ Besides, his model of the addictive family is accepted in therapeutic and rehabilitation communities much more widely than Steinglass.

\section{Adult children of alcoholics}

Many children from families with alcoholism become alcoholics or marry someone who has a compulsive, addictive personality disorder. This confirms the thesis that the family is a system rather than an isolated element, and that alcoholism is not only a problem of an individual, but also of his primary family. Likewise, many who are cured of alcoholism and successfully abstain, still suffer compulsion in other areas; which can support the thesis of an addictive personality - the system still needs addiction, the individual has not yet learned to regulate painful feelings in ways other than addiction. Children of adult alcoholics have many common features that are not only related to alcohol, but also to how they express anger, how they cope with the need to control others, how they react to an emotionally inaccessible alcoholic parent. These responses are the answer to the trauma of rejection and shame resulting from rejection. ${ }^{39}$ In children of alcoholics,

38 Alcoholics Anonymous, A.A. tradition: our experience has taught us, New York 1947, Works Publishing, Inc.

39 J. Middelton-Moz, L. Dwinell, After the tears: helping adult children of alcoholics heal their childhood trauma, Rev. \& expanded. ed. Deerfield Beach, Fla. 2010, Health Communications, p. 15. 
shame is primarily due to inappropriate relationships with parents and, as a result, they have problems in various relationships. Here we can search for the source of compulsion. The tendency towards pathological relationships arises from the aforementioned feeling of shame, which is the result of rejection by one's parents. ${ }^{40}$

These children typically deny their partners' or parents' problems with alcohol. The reason for this is an imaginary bond, by means of which they idealize their parents or the non-drinking parent. At the same time, they minimize or deny their own feelings and the impact that the alcoholism of their parents or partner has on them. Because they deny their feelings, they do not know what they feel, and therefore they cannot express it. They often criticize themselves excessively or they project their own excessive self-criticism to others. They lack appropriate boundaries, and often find it difficult to distinguish between their feelings, problems and responsibilities, and those of others. They therefore tolerate actions that they otherwise would not have. As a result, they have problems in intimate relationships. For them it is difficult to take adequate care of themselves: either they feel guilty or they are too aggressive in doing so. ${ }^{41}$

Children of alcoholics are often compulsive, grandiose and have problems with decision-making. They try to control what cannot really be controlled. In their behaviour they often exaggerate and respond impulsively, without reflection. They are concerned with what others think about them. They feel as if they cannot belong to anyone, so they feel inferior, hiding behind various roles such as the caretaker, the overly responsible family member, the hero, the star, the addict, or the perfectionist. They usually choose partners whom they can help because they substitute love for pity. ${ }^{42}$ In primary relationships, i.e. in childhood, they were either emotionally, physically or sexually abused. Consequently, they choose the role of a victim or a perpetrator in adulthood. They often feel unconscious fear and suffer from catastrophic expectations, and they feel they must be constantly alert.

\footnotetext{
40 J. Bradshaw, Bradshaw on--the family: a revolutionary way of self-discovery, Pompano Beach, Fla. 1988, Health Communications, pp. 98-109.

41 W. Kritsberg, The adult children of alcoholics syndrome: from discovery to recovery, Pompano Beach, Fla. 1986, Health Communications, p. 35.

42 J. Middelton-Moz, L. Dwinell, After the tears: helping adult children of alcoholics heal their childhood trauma, Rev. \& expanded. ed. Deerfield Beach, Fla. 2010, Health Communications, p. 15.
} 
They often have problems with concluding certain important things in their lives, such as studies, inadequate jobs or inappropriate relationships.

\subsection{The feeling of rejection in adult children of alcoholics}

Due to chronic disorders in the family with alcoholism, each member must adapt to this situation in their own way. This makes them very cautious, anxious and chronically worried. In such an atmosphere, it is difficult for individuals to take care of their basic needs. The result is low self-esteem. The main consequence of chronic stress is the feeling of rejection ${ }^{43}$. The alcoholaddicted parent spends most of his time drinking and not much time is left for children. Therefore, physical and emotional rejection is always present in a family where one of the parents has problems with alcoholism.

Another form of rejection is the neglect of the child's need for belonging. ${ }^{44}$ This happens when the child has no close person to whom he could relate, who would mirror his feelings, experiences and needs. If the father is an alcoholic and the mother depends on him, she is co-dependent and consequently less accessible for the child. ${ }^{45}$ As a result of unsatisfied narcissistic needs, the child creates imaginary bonds with both parents and develops the, so-called, self-rewarding mood-changing habits, which divert his attention from the painful reality.

The third form of rejection stems from various forms of abuse. The result of excessive alcohol consumption is that an intoxicated individual has lower self-control and there is a higher chance for him to violate boundaries. The likelihood of emotional, physical or sexual abuse in addictive families is, therefore, higher. ${ }^{46}$

Violated boundaries within family are another form of rejection. ${ }^{47}$ For this reason, the child in such a family feels trapped in satisfying his parents'

43 J.C. Friel, L.D. Friel, Adult children: the secrets of dysfunctional families. Pompano Beach, Fla. 1988, Health Communications, p. 35.

44 T. Dayton, The ACoA trauma syndrome: the impact of childhood pain on adult relationships, Deerfield Beach, Fla. 2012, Health Communications, p. 83.

45 J.C. Friel, L.D. Friel, Adult children: the secrets of dysfunctional families. Pompano Beach, Fla. 1988, Health Communications, p. 35.

46 J. Bradshaw, Bradshaw on--the family: a revolutionary way of self-discovery, Pompano Beach, Fla. 1988, Health Communications, p. 104.

47 J.C. Friel, L.D. Friel, Adult children: the secrets of dysfunctional families. Pompano Beach, Fla. 1988, Health Communications, p. 35. 
needs, as well as in meeting the systemic needs for wholeness and balance. By doing so, he is unable to take care of his own needs. Chronic rejection results in compulsivity. ${ }^{48}$ These children feel anxiety and emptiness because they have not been adequately taken care of, and this emptiness will keep driving their compulsive behaviour.

\subsection{Imaginary bond in children in the family with alcoholism}

Once the interpersonal relationship with his parents is broken, the child will hardly find anyone to be deeply attached and belong to, so he will replace this need with an imaginary bond ${ }^{49}$ and self-indulgent, addictive moodchanging behaviour. In this way, compulsiveness is established.

The imaginary bond is also the basis of pathological relationships, a part of which are unrealistic expectations and denials. In fact, addiction is a form of an imaginary bond that was shaped in childhood, at the same time as an imaginary fantasy world, and in adulthood, this fantasy, illusory world is maintained by means of addictive behaviour or alcoholic intoxication. All addictions are actually about the establishment or reawakening of the illusion of re-bonding. At that time, the individual does not feel lonely any more. Illusion and denial protect him from real pain and suffering that emanates from emptiness and loneliness.

\subsection{Compulsive emotions and thinking}

Sensations can also be addictive or compulsive. ${ }^{50}$ A painful feeling can be replaced by another, less painful one. Many men replace the feeling of fear with the feeling of anger that is more socially acceptable for a man who is supposed to be strong, firm and fearless. Any feeling can be used to change the mood. If this redirection harmfully affects one's life, we speak of addiction. Similarly to substituting feelings, forms of thinking can also help the individual to redirect and change his current experience. These forms

\footnotetext{
48 J. Bradshaw, Bradshaw on--the family: a revolutionary way of self-discovery, Pompano Beach, Fla. 1988, Health Communications, p. 108.

49 R.W. Firestone, J. Catlett, Fear of intimacy, Washington, D.C.; London 1999, American Psychological Association, p. 41.

50 J.C. Friel, L.D. Friel, Adult children: the secrets of dysfunctional families. Pompano Beach, Fla. 1988, Health Communications, p. 35.
} 
are: obsessive care of unnecessary things, excessive attention to irrelevant details, and abstract thinking. ${ }^{51}$ There are obsessive mental patterns when an addict ruminates for hours about how he will get drunk, or take a drug, or get involved in an addictive behaviour.

\section{Conclusion}

In the light of the above, it should be emphasized that in the treatment of compulsiveness, undistorted thinking is very important: the individual should be aware of what was going on in his primary family, how he felt and how he reacted, and what defence mechanisms he established. It is important that he is aware of the connection between his current compulsive behaviour and what caused this addiction. Of course, this does not mean that he is not responsible for his treatment and for stopping his compulsive behaviour, but he is not responsible for how the compulsiveness emerged in the first place, that is, for his feelings of loneliness, rejection, sadness, anger, and shame in the first years of his life. When he is aware that his addictive behaviour does not speak of who and what he is, but primarily of what happened to him, it is easier to start or continue the healing process.

\section{Bibliography}

Alcoholics Anonymous, A.A. tradition: our experience has taught us, New York 1947: Works Publishing, Inc.

Astrei G., Bevere A., Starševske zmote, Celje 2009: Celjska Mohorjeva družba; Društvo Mohorjeva družba.

Bradshaw J., Bradshaw on--the family: a revolutionary way of self-discovery, Pompano Beach, Fla. 1988: Health Communications.

Bradshaw J., Healing the shame that binds you, Deerfield Beach 1988: Health Communications.

51 J. Middelton-Moz, L. Dwinell, After the tears: helping adult children of alcoholics heal their childhood trauma, Rev. \& expanded. ed. Deerfield Beach, Fla. 2010, Health Communications, p. 15. 
Bradshaw J., Homecoming: reclaiming \& championing your inner child, London 1990: Bantam Books.

Bradshaw J., Creating love: the next great stage of growth, London 1992: Bantam Books.

Bradshaw J., Family secrets: what you don't know can hurt you, London 1995: Bantam Books.

Bradshaw J., Reclaiming virtue: Reclaiming Virtue: How We Can Develop the Moral Intelligence to Do the Right Thing at the Right Time for the Right Reason, London 2009: Piatkus.

Dayton T., The ACoA trauma syndrome: the impact of childhood pain on adult relationships, Deerfield Beach, Fla. 2012: Health Communications.

Firestone R. W., Catlett J., Fear of intimacy, Washington, D.C.; London 1999: American Psychological Association.

Flores P., Addiction as an attachment disorder, 2004: Jason Aronson.

Friel J. C., Friel L. D., Adult children: the secrets of dysfunctional families. Pompano Beach, Fla. 1988: Health Communications.

Gostečnik C., Človek v začaranem krogu, Ljubljana 1997: Brat Frančišek.

Gostečnik C., Relacijska družinska terapija, Ljubljana 2004: Brat Frančišek.

Gostečnik C., Sistemske teorije in praksa, Ljubljana 2010: Brat Frančišek.

Gostečnik C., Inovativna relacijska družinska terapija, Ljubljana 2011: Brat Frančišek.

Kritsberg W., The adult children of alcoholics syndrome: from discovery to recovery, Pompano Beach, Fla. 1986: Health Communications.

Levin J. D., Couple and family therapy of addiction, Northvale, N.J.; London 1998: Jason Aronson.

Love P., Robinson J., The emotional incest syndrome: what to do when a parent's love rules your life, New York 1990: Bantam Books.

Middelton-Moz J., Dwinell L., After the tears: helping adult children of alcoholics heal their childhood trauma, Rev. \& expanded. ed. Deerfield Beach, Fla. 2010: Health Communications.

Miller A., For your own good: hidden cruelty in child-rearing and the roots of violence, London 1983: Farrar, Straus, Giroux.

Stala J., Geistig behinderte Kinder religiös erziehen - Herausforderungen an Pädagogik und Katechese, „The Person and the Challenges” 4 (2014) nr 2, pp. 221-234. 
Stala J., Der gesellschaftlich-kulturelle Kontext der aktuellen Gefährdungen für die religiöse Erziehung und Bildung in der Familie, „The Person and the Challenges" 3 (2013) nr 1, pp. 251-266.

Stala J., Der Mensch als Person: Die bestimmende Grundlage für Johannes Paul II. in seinem Bild von der Familie, „The Person and the Challenges” 2 (2012) nr 2, pp. 41-59.

Steinglass P., The Alcoholic Family, New York 1987: Basic Books.

Wolin S. J., Bennett L. A., Family rituals, "Family process" 23 (1984) Nr. 3, pp. 401-420.

Wolinsky S., Ryan M. O., Trances people live: healing approaches in quantum psychology, Falls Village, CT 1991: Bramble Company. 
